\title{
Apresentação
}

\section{Além do livro: literatura e novas mídias}

\author{
Rejane C. Rocha ${ }^{1}$
}

Pode-se iniciar com uma provocação:

Teremos de voltar ao jardim de infância. Teremos de retornar àquele nível em que ainda não tínhamos aprendido a ler e a escrever. Nesse jardim de infância, aprenderemos com computadores, plotadoras e jogos infantis semelhantes a gadgets. Teremos de utilizar os aparelhos complexos e sofisticados, fruto de um desenvolvimento espiritual de milhares de anos, com propósitos infantis. Não nos denominaremos de idiotas atrasados quando ficarmos brincando de maneira tão desastrada, mas de artistas inovadores da computação gráfica. E, servindo-nos do alfabeto, escreveremos comentários eruditos e patéticos acerca de nossas brincadeiras, a fim de gabarmo-nos diante de nós mesmos e de todos aqueles que continuam a escrever e a pensar pautados no método antigo. O que faremos, quando sentarmos diante de nossos minitels, apples e commodores, será de tal forma primitivo que nem mesmo com simpósios, oficinas e seminários conseguiremos ludibriar alguém acerca disso (Flusser, 2010, p. 172).

A citação foi extraída do último capítulo, de contornos conclusivos, do livro de Vilém Flusser A escrita: há futuro para a escrita? e, se assume contornos provocativos aqui, na apresentação de um dossiê dedicado ao tema "Literatura e novas mídias", não tem esse significado no seu contexto original, muito embora se possa identificar um acento bastante irônico no que era, no momento de concepção do texto, uma aposta profética. ${ }^{2}$ Era, porque embora algo catastrófica, o que a citação prevê é o imenso abismo a separar, na atualidade, os nativos digitais dos migrantes digitais, nós ${ }^{3}$ de volta ao jardim de infância brincando com

\footnotetext{
${ }^{1}$ Doutora em estudos literários e professora da Universidade Federal de São Carlos (UFSCar), São Carlos, SP, Brasil. E-mail: rjncris@gmail.com

${ }^{2}$ O livro foi publicado na Alemanha, pela primeira vez, em 1987. Em 1989 ganhou uma segunda edição, revisada pelo autor. Foi traduzida no Brasil em 2010.

${ }^{3}$ Os que se encontram na casa dos 40 anos.
} 
gadgets. Ainda que a citação de Flusser seja lida apenas como uma profecia irônica, é inegável que ela nos provoca no sentido de que o panorama que o filósofo tcheco-brasileiro antevê é este no interior do qual devemos compreender a literatura contemporânea: um contexto em que se deve reaprender a lidar com as linguagens, verbais e não verbais, transcodificadas ${ }^{4}$ pela linguagem digital. Esse mesmo contexto também é delineado de forma perturbadora por outro pensador contemporâneo, Néstor García Canclini. O capítulo "Abertura" do seu Leitores, espectadores, internautas (2007, p. 11) começa assim:

Você está dirigindo o carro enquanto ouve um áudio-livro e é interrompido por uma ligação no celular. Ou você está em casa, sentado numa poltrona, com o romance que acabou de comprar, enquanto na televisão ligada à espera do noticiário passam um anúncio sobre as novas funções do iPod. Você se levanta e vai até o computador para ver se compreende essas novidades que não estão mais nas enciclopédias de papel e, de repente, percebe quantas vezes, mesmo para procurar dados sobre outros séculos, recorre a esses novos patrimônios da humanidade que se chamam Google e Yahoo.

A reflexão de Canclini (2007) que se segue a essa "Abertura" desenvolve-se a partir de um pressuposto bastante incômodo para os que se dedicam ao estudo da literatura, o de que a cultura contemporânea não mais se organiza em torno do eixo letrado, e já há algum tempo. A afirmação só pode ser um pressuposto porque, em 2007, data da publicação do livro de Canclini e 20 anos depois da publicação do livro de Vilém Flusser, aquilo sobre o que pensava este autor já se cumpriu, já não é mais uma profecia e a citação da página inicial de "Abertura" poderia até ser lida como a descrição daquele "jardim de infância" de que falava o filósofo tcheco-brasileiro.

Provocativas e incômodas, as citações com que se abre essa apresentação questionam, afinal, qual é a possibilidade de o que se compreende por literatura desde, pelo menos, o século XVIII, ${ }^{5}$ sobreviver como expressão cultural significativa e representativa nesse contexto caracterizado pela ubiquidade das mídias, pela transcodificação das

\footnotetext{
${ }^{4}$ O termo é também de Vilém Flusser, no mesmo livro. Ver capítulo "19. Transcodificar".

5 Acompanho, no estabelecimento desse período como o da "institucionalização" da literatura, a reflexão de Paul Zumthor (1989).
} 
linguagens em linguagem digital, pelas novas práticas de leitura que não mais se restringem à página impressa.

Não é simples responder a esse questionamento, dada a complexidade do fenômeno literário, que não se limita a injunções de ordem estética, que poderiam ser encontradas dentro dos limites que se desenham pela sua textualidade, mas envolve uma intricada rede de outros elementos que se articulam entre si, todos a suscitarem outros questionamentos: a produção (escrita, edição e publicação), a leitura, a circulação. O desafio é, então, compreender esse feixe complexo de elementos em um contexto em que escrever e publicar, ler e legitimar um texto como literário se faz no interior da ubiquidade das mídias, a partir da linguagem digital, em suportes de leitura eletrônicos.

Os autores que compõem este dossiê não se furtam a enfrentar o desafio. A partir de diferentes abordagens teórico-críticas acerca da literatura no contexto da contemporaneidade digital e desfiando o feixe de complexidades que constituem o fenômeno literário, contribuem para o desenvolvimento de um debate que ainda requer adensamento no campo dos estudos literários brasileiros.

Os artigos que abrem este volume dedicam-se a compreender, seja pelo estudo de casos específicos, seja pela reflexão mais ampla e geral, quais são os circuitos de circulação da literatura no momento da emergência das mídias digitais. Pensar a respeito de como os textos literários chegam aos leitores, como esses leitores os compartilham entre si, de que maneira se dá o contato com um leitor "pessoalizado" 6 que interfere, às vezes diretamente, na produção de um texto que foi compartilhado em redes sociais, por exemplo, é enfrentar, também, questões relativas à legitimação de um texto como literário, ao valor literário que se atribui a um texto, à constituição do campo literário na contemporaneidade digital.

Partindo de uma reflexão acerca da lírica moderna, de seus traços de brevidade, concentração e autorreflexão crítica, Márcio Prado investiga, em seu artigo "Faces da literatura contemporânea: o caso da poesia viral", o que denomina como "poesia viral": expressão poética que, na contemporaneidade, é produzida e veiculada por meio das mídias digitais - redes sociais, fanpages, sites e blogs. Para além de uma

${ }^{6} \mathrm{O}$ termo é de Paulo Franchetti, que o utilizou na palestra "Poesia em espaço digital", ministrada no Programa de Pós-Graduação em Estudos de Literatura da UFSCar, no dia 10 de junho de 2015. 
discussão que argumenta a respeito do necessário questionamento dos valores que sustentaram a lírica moderna, sob o risco de simplesmente se ignorar essa produção poética contemporânea, o autor ainda reflete sobre o tema no âmbito da pesquisa na área de literatura e do ensino de literatura nos diferentes níveis escolares. A abordagem, provocativa e instigante, clama pelo abandono de preconceitos e pela aposta no enfrentamento do problema.

É também sobre a circulação da poesia a reflexão de Sayonara Amaral de Oliveira que, ao estudar um site dedicado a um projeto poético em atividade desde 2006, persegue as especificidades de uma parcela do campo literário que se desenvolve nos múltiplos ambientes das novas mídias digitais. Poetrix, como é chamado o movimento alojado no site Recanto das Letras, fornece interessante material para a reflexão acerca das reinstitucionalizações pelas quais tem passado a literatura desde que outras formas de produção, circulação e leitura do texto literário - no caso, do texto poético - têm se tornado possíveis em espaços como sites, blogs, redes sociais. É nesse sentido que a autora identifica estratégias que garantem ao movimento Poetrix uma legitimidade diversa daquela que um movimento poético alcançaria por meios, digamos, "convencionais". Tais estratégias, a saber, a colaboração entre autores e entre estes e os leitores, a produção de reflexão metapoética, a concepção de manifestos, a promoção de eventos e concursos se não são propriamente uma novidade no estabelecimento do campo literário, surgem apropriadas e reconfiguradas pelo movimento, que parece ter consciência tanto de sua vinculação à tradição poética quanto das potencialidades que esses novos espaços de inscrição do literário representam.

Se a discussão a respeito do literário no contexto digital pressupõe uma rearticulação da metalinguagem crítica, uma revisão de parâmetros de valoração e uma aposta no vir-a-ser da literatura digital, não menor esforço deve haver na compreensão dos novos espaços de circulação em que se inscrevem e se disseminam textos novos e nem tão novos assim. Esse é o enfrentamento a que se propõe Luciana Salazar Salgado, no artigo "Sobre a produção de valor: a recente circulação do poema 'Viva Vaia', de Augusto de Campos", ao discutir não só um texto literário, mas um "caso" da cibercultura que evidencia algo de que nem sempre se lembra: o que chamamos de textos literários e obras literárias fazem parte de um complexo e instável universo que vai muito além da 
matéria verbal - por mais bem acabada que ela seja - pressupondo uma intricada rede que faz circular, ressoar, renascer textos e autores.

O "caso Viva Vaia" mostra que os espaços de circulação do texto literário - do livro para capas de discos, para roupas, para o jornal - em muito abala o traço da integridade que, segundo Reinaldo Laddaga (2002), é um dos pressupostos básicos do que designamos por obra artística e literária. Por isso, é fundamental compreender que a produção de significados pelos textos diz respeito, também, às materialidades de inscrição desses textos. Essa é uma das teses caras a Roger Chartier, que Ana Elisa Ribeiro resgata a fim de compreender o panorama atual de emergência de outros processos de escrita, edição e leitura do texto literário. A autora propõe investigar, no artigo "Questões provisórias sobre literatura e tecnologia: um diálogo com Roger Chartier", esse panorama tão desafiador em termos de movimentos para, a um só tempo, resguardar-se do determinismo tecnológico que frequentemente ronda a reflexão sobre as novas mídias e ressaltar as relações inextricáveis entre a cultura impressa e a digital, na atualidade.

Fechando esse primeiro bloco de artigos em que a temática principal - mas não a única - diz respeito à questão da circulação da literatura no contexto digital, Alamir Aquino Corrêa, no artigo "Literatura: contexto digital, hipercolonialismo e materialidades" articula ao conceito de "hipercolonialismo", proposto por Amelia Sanz, a discussão a respeito da produção, leitura, circulação e valoração dos objetos literários digitais. Sobrevêm da reflexão proposta questões, talvez ainda sem respostas, sobre de que forma a propalada tese da democratização do conhecimento por meio da informática pode ser pensada como uma falácia à qual todos devemos ficar atentos.

Um dos desafios da abordagem analítica de textos literários que efetivamente fazem uso das possibilidades técnicas das novas mídias digitais e que dificilmente poderiam ser apreendidos em outro suporte, que não a tela conectada em rede, é a escassez de uma metalinguagem capaz de apreender criticamente a relação inextricável que, nos objetos bem realizados, se estabelece entre a matéria verbal e a imagem, o som, a cinestesia. Dois artigos deste dossiê enfrentam o problema, tateando possibilidades. Daniela Côrtes Maduro em "Histórias por um fio: narração mediada em tempo real" analisa diversas narrativas produzidas em Portugal, observando que o que as une - para além do 
meio escolhido para a sua elaboração, inscrição e circulação - é o fato de que todas propõem um esgarçamento não só do próprio conceito de narrativa, mas também da própria possibilidade de sua efetivação. Isto porque, no caso dessas histórias, a mediação feita pelo computador e a narrativa em tempo real interpõem tantos "ruídos", que seu cumprimento só se dá sob o risco iminente da não realização, da não narratividade, da não inteligibilidade.

Minha proposta analítica a respeito da obra Oratório, de André Vallias, está relacionada com a tentativa de observar como a forma do que poderíamos designar como literatura digital pressupõe a reelaboração de linguagens e códigos diversos a partir do computador ligado em rede. Obra compósita por definição e, por isso, representativa do nosso tempo, Oratório, de André Vallias, rasura a integridade, pressuposto crítico do conceito de obra artística e impõe-me o desafio de sua análise, que faço a partir dos conceitos críticos da teoria e crítica literárias, sem, contudo, descurar da importância dos elementos não verbais, que, nessa obra, assumem importância significativa idêntica a dos elementos verbais.

O percurso de Glaucia Guimarães e Maria Cristina Cardoso Ribas em "Literatura infantil na sociedade multimidiática" é também analítico, mas em direção diversa. Isso porque as autoras preocupam-se, em seu artigo, em refletir a respeito de um livro infantil impresso que busca estimular uma prática de leitura que é característica dos livros digitais. As autoras identificam uma relação intertextual e interdiscursiva do objeto impresso que analisam com os textos multimidiáticos que articulam diferentes linguagens e captam a atenção pelo recurso da interação, do jogo, concluindo que, embora reproduza na forma impressa os recursos de um objeto digital, o livro em questão não prescinde da linguagem pedagógica, marca de muito do que se produz em termos de literatura para crianças e jovens.

$\mathrm{O}$ artigo que encerra este dossiê dedica-se primordialmente à questão da leitura literária no contexto digital. O objetivo da discussão empreendida por Edgar Roberto Kirchof em "Como ler os textos literários na era da cultura digital?" é, em um primeiro momento, mapear as principais problemáticas concernentes à maneira como a leitura nas telas tem influenciado o que a cultura letrada designa como leitura e que, nem de longe, como demonstra o autor, é um ato homogêneo, realizado da mesma forma, por todos os leitores e em todas 
as ocasiões. Lembrando disso, o autor pondera que a leitura da literatura digital é complexa tanto quanto qualquer outro tipo de leitura literária e que essa requer um "letramento digital crítico", que permita ao leitor apreender a textualidade digital para além de seus recursos técnicos, de modo a se resguardar dos interesses da indústria cultural e do marketing, por exemplo.

Findo o percurso pelas propostas reflexivas deste dossiê, a provocação com a qual o iniciamos e à qual seria inútil tentar responder ainda ressoa, uma vez que provocações nos tiram da zona de conforto e é nisso que reside o seu mérito. Os textos aqui reunidos demonstram que seus autores aceitaram-na, enfrentaram-na, e, valendo-se de suas diversas abordagens teórico-crítico-metodológicas converteram-se em

Los vigilantes de la metamorfoses [que] no debieran permitir-se engrosar la lista de "analfabetos" informáticos y permanecer al otro lado de la brecha que empieza a distinguir entre el común de los ciudadanos y las nuevas élites de creadores y gestores de las formas emergentes de cultura digital. No se trata de convertirnos en programadores [...] Se trata simplemente de afrontar los retos del nuevo entorno comunicativo y sus consecuencias socioculturales en nuestro ámbito de investigación y docencia, la literatura y el pensamiento literario (Sánchez-Mesa, 2004, p. 33).

\section{Referências}

CANCLINI, Néstor García (2008). Leitores, espectadores, internautas. São Paulo: Iluminuras.

FLUSSER, Vilém (2010). A escrita. Há futuro para a escrita? São Paulo: Annablume.

LADDAGA, Reinaldo (2002). Uma fronteira do texto público: literatura e meios eletrônicos. In: OLINTO, Heidrum Krieger; SCHOLLHAMMER, Karl Erik (Org.) Literatura e mídia. Rio de Janeiro: PUC-Rio; São Paulo: Loyola, p. 17-31.

SÁNCHEZ-MESA, Domingo (2004). Los vigilantes de la metamorfosis. El reto de los estúdios literarios ante las nuevas formas y medios de comunicación digital. In: SÁNCHEZ-MESA, Domingo (Coord.). Literatura y cibercultura. Madrid: Arco libros, p. 11-36.

ZUMTHOR, Paul (1987). La letra y la voz. Tradução de Julián Presa. Madri: Cátedra. 